\title{
Sorption of I and Se onto Green Rusts with Different Interlayer Anions, $\mathrm{GR}\left(\mathrm{CO}_{3}{ }^{2}\right)$ AND $\mathrm{GR}(\mathrm{Cl})$
}

\author{
J. H. Min, M. H. Baik*, J. K. Lee, and J. T. Jeong
}

Korea Atomic Energy Research Institute

\begin{abstract}
Natural green rust (GR) can retard the migration of anions through geological media because it has a Layer Double Hydroxyl (LDH) structure with a positive charge. In this study, the sorption behaviors of anions such as selenite $\left(\mathrm{Se}(\mathrm{IV}) \mathrm{O}_{3^{2-}}\right)$, selenate ( $\left.\mathrm{Se}(\mathrm{VI}) \mathrm{O}_{4^{2-}}\right)$, and iodide (I-) onto green rusts with different structures, i.e., $\left.\mathrm{GR}(\mathrm{Cl})^{-}\right)$ and $\mathrm{GR}\left(\mathrm{CO}_{3}{ }^{2-}\right)$, were investigated by conducting batch sorption experiments in an anoxic condition. Experimental results showed that selenite was mostly sorbed onto $\mathrm{GR}\left(\mathrm{CO}_{3}{ }^{2-}\right)$ and then partly reduced to metal selenium, $\mathrm{Se}(0)$. However, little selenate and iodide was sorbed onto $\mathrm{GR}\left(\mathrm{CO}_{3}^{2-}\right)$ while some iodide was sorbed onto $\mathrm{GR}(\mathrm{Cl})$. It is presumed from the experimental results that the major sorption mechanism of $\mathrm{SeO}_{3}{ }^{2-}$ and $\mathrm{I}$ onto green rusts is the anion exchange reaction with the anions existing in the interlayer of the rusts. Green rust, therefore, can play an important role in the retardation of anions migrating through deep geological environments owing to its LDH structure with a high anion exchange capacity.
\end{abstract}

Keywords : Green rust, Selenium, Iodide, Anion exchange, Sorption, Reduction

\section{INTRODUCTION}

In a proposed geological disposal system for highlevel radioactive waste in Korea, metal canisters and compacted bentonite clay have been considered as engineered barriers [1]. Based on the Korean disposal concept, a metal canister containing high-level radioactive waste is installed into a compacted bentonite buffer emplaced in disposal boreholes located in a deep underground repository. The proposed metal canister is made of iron, and its exterior is coated with a corrosion-resistant copper metal [1]. In deep geological conditions for the disposal of high-level radioactive wastes, the iron canister will corrode into green rust (GR) and magnetite [2-4]. The dissolution of $\mathrm{Fe}$ (II) on the surface of the iron canisters will proceed to corrosion of the iron canisters as follows: $\mathrm{Fe}(\mathrm{II}) \rightarrow \mathrm{Fe}(\mathrm{II})(\mathrm{OH})_{2}$ and/or $\mathrm{Fe}(\mathrm{III})(\mathrm{OH})_{3} \rightarrow$ green rust $(\mathrm{GR}) \rightarrow$ lepidocrocite or magnetite $\rightarrow$ goethite or hematite etc. [5-7].

GR is a natural corrosion product of stainless steel and iron that can be formed in compacted bentonite and rein-

Received : July 05, 2013 - Revised : July 31, 2013 - Approved : August 08, 2013

*Corresponding Author : M. H. Baik

Korea Atomic Energy Research Institute

Tel : +82-42-868-2089 E-mail : mhbaik@kaeri.re.kr

Daedeokdaero 989-111, Yuseong-gu, Daejeon 305-353, Republic of Korea forced concrete $[8,9]$, in seawater $[10,11]$, and in water supply pipes [12]. GR is known to exist in a stable state when the environment is near a transition zone between $\mathrm{Fe}(\mathrm{II})$ and $\mathrm{Fe}(\mathrm{III})$ or between the oxidized and reduced layers of underground environments. GR is thus considered one of the major corrosion products of iron canisters in deep geological conditions for radioactive waste disposal $[3,4,13]$.

Radionuclides such as selenium, iodine, and technetium present as anions in geological environments are of great concern in the context of radioactive waste disposal because of their limited sorption onto geologic materials [14]. In particular, selenium exists in various chemical species with different oxidation states such as $\mathrm{Se}(-\mathrm{II}), \mathrm{Se}(0), \mathrm{Se}(\mathrm{IV})$, and $\mathrm{Se}(\mathrm{VI})$ under most geochemical conditions (see Fig. 1). Iodine usually exists as iodide (I-) under most geochemical conditions [15].

GR composed of a mixture of $\mathrm{Fe}(\mathrm{II})$ and $\mathrm{Fe}(\mathrm{III})$ is a very sensitive iron oxide with respect to oxidation and a very strong reducing agent. In particular, surface-bound $\mathrm{Fe}(\mathrm{II})$ species have been reported to have a stronger reducing potential than $\mathrm{Fe}$ (II) species dissolved in a solution[5]. The formation of GR depends upon the $\mathrm{Fe}(\mathrm{II}) / \mathrm{Fe}$ (III) ratio and $\mathrm{pH}$, and the former ranges between 1 and 4.5 [16]. The chemical formula of GR is generally given as $[17,18]$ :

$$
\left.\left[\mathrm{Fe}(\mathrm{II})_{(\mathrm{I-x})} \mathrm{Fe}(\mathrm{III})_{\mathrm{x}}(\mathrm{OH})_{2}\right]^{\mathrm{x}+} \cdot\left[(\mathrm{x} / \mathrm{n}) \mathrm{A}^{\mathrm{n}-}\right) \cdot \mathrm{mH}_{2} \mathrm{O}\right]^{\mathrm{x}-}
$$




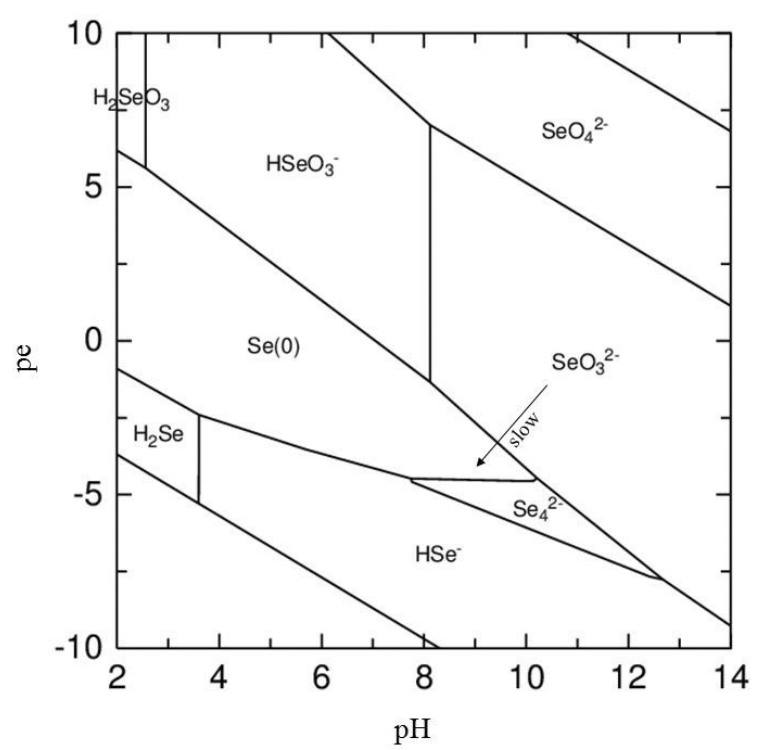

Fig. 1. Eh-pH diagram for $1.3 \times 10^{-5} \mathrm{M}$ selenium under the experimental conditions calculated by PHREEQC 3.0 code using the thermodynamic data from Iida et al. [25]. The arrow shows that the reduction of $\mathrm{Se}(\mathrm{IV}) \mathrm{O}_{3^{2-}}$ into $\mathrm{Se}(0)$ is a slow process.

where

$\mathrm{x}=[\mathrm{Fe}(\mathrm{III})] /([\mathrm{Fe}(\mathrm{II})]+[\mathrm{Fe}(\mathrm{III})])$,

$\mathrm{A}^{\mathrm{n}-}=$ donated interlayer anions with $\mathrm{n}^{-}$charge, and

$\mathrm{m}=$ the mole of water molecules.

GR is a member of a family of minerals called Layered Double Hydroxides (LDH) and has been of interest owing to its potential application as an anion exchanger. LDH structured materials are usually used as anion exchangers with high selectivity by their inherent composition [19]. In the LDH structure of GR, Fe(III) produces a positive charge in the GR layers where the positive charge is balanced by anions such as $\mathrm{Cl}, \mathrm{CO}_{3}{ }^{2-}$, and $\mathrm{SO}_{4}{ }^{2-}$ existing in the interlayer of GR. The interlayer distance of GR depends upon the anion species and structure [20-22]. Different interlayer distances of GR according to the different anions in the interlayer of GR are shown in Fig. 2.

The sorption of anions onto GR can occur by anion exchange with interlayer anions of GR and chemical adsorption onto edge sites of GR, leading to the formation of surface complexes, depending on the types of GR, sorbing anions, and chemical conditions [23, 24]. In this study, we focused on the anion exchange process of GR rather than chemical adsorption. GR as an anion exchanger and a strong reducer can influence the migration of anions in geochemical conditions relevant to a radioactive waste repository. However, the sorption behaviors of GR are not fully understood. Therefore, the purpose of this paper is to investigate the sorption behavior of major anions such as selenite ( $\left.\mathrm{Se}(\mathrm{IV}) \mathrm{O}_{3}{ }^{2-}\right)$, selenate ( $\left.\mathrm{Se}(\mathrm{VI}) \mathrm{O}_{4}{ }^{2-}\right)$, and iodide (I-) onto GR with different structural anions.

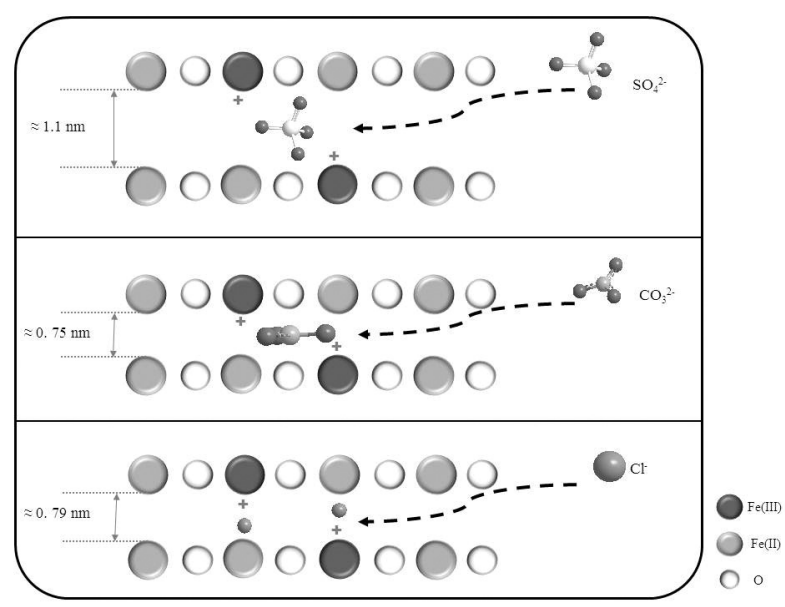

Fig. 2. Ionic bonds of anions $\left(\mathrm{Cl}, \mathrm{CO}_{3}{ }^{22}\right.$, and $\left.\mathrm{SO}_{4}{ }^{2}\right)$ on the positive sites of $\mathrm{Fe}(\mathrm{III})$ in the interlayer of GR.

\section{EXPERIMENTAL}

\subsection{Materials and apparatus}

All chemical solutions were prepared in nitrogenpurged deionized water with resistivity of $18.2 \mathrm{M} \Omega-\mathrm{cm}$ (Milli-Q water (Millipore)). When GR was synthesized, airtight glass bottles with rubber stoppers were used to prevent the oxidation of $\mathrm{Fe}(\mathrm{II})$, because $\mathrm{Fe}(\mathrm{II})$ can easily oxidize into $\mathrm{Fe}(\mathrm{III})$ even in an anaerobic glove box. Polypropylene (PP) bottles were used for other stock solutions. All chemicals $\left(\mathrm{Na}_{2} \mathrm{Se}(\mathrm{IV}) \mathrm{O}_{3}, \mathrm{Na}_{2} \mathrm{Se}(\mathrm{IV}) \mathrm{O}_{4}\right.$, $\mathrm{NaI}, \mathrm{Fe}(\mathrm{II}) \mathrm{Cl}_{2} \cdot 4 \mathrm{H}_{2} \mathrm{O}, \mathrm{Fe}(\mathrm{III}) \mathrm{Cl}_{3} \cdot 6 \mathrm{H}_{2} \mathrm{O}, \mathrm{Na}_{2} \mathrm{CO}_{3}, \mathrm{NaCl}$, and $\mathrm{NaClO}_{4}$ ) used in the experiments were above proanalysis grade.

All experiments were conducted in an anoxic glove box under a nitrogen and hydrogen atmosphere $\left(96 \% \mathrm{~N}_{2}\right.$ and $\left.4 \% \mathrm{H}_{2}, \mathrm{O}_{2}<10 \mathrm{ppm}\right)$ at room temperature. A pH electrode (Orion 8103 B12) and an Eh electrode (Orion 9778 BMWP) connected with an electrometer (Orion 4 star) were used for $\mathrm{pH}$ and $\mathrm{Eh}$ measurements. The electrodes were calibrated using three $\mathrm{pH}$ buffer solutions $(\mathrm{pH} 4.01$, 7.00, and 10.01) and one redox standard solution ( +420 $\mathrm{mV}$ ), respectively. After the sorption experiment, the solution was separated from the solid using polyethersulfone (PES) syringe micro-filters (Millipore) with a pore size of $0.22 \mu \mathrm{m}$. The concentrations of selenium and iodide were analyzed by inductively-coupled plasma optical emission spectrometry (ICP-OES, Thermo Scientific iCAP 6500 DUO) or inductively- coupled plasma mass spectrometry (ICP-MS, BRUKER 820-MS). 


\subsection{Synthesis of GR}

\subsubsection{GR carbonate, $\mathrm{GR}\left(\mathrm{CO}_{3}{ }^{2-}\right)$}

GR carbonate, $\mathrm{GR}\left(\mathrm{CO}_{3}{ }^{2}\right)$, was synthesized using the method of Taylor et al. [25]. Two separate $100 \mathrm{~mL}$ solutions of $1 \mathrm{M} \mathrm{Fe}(\mathrm{II}) \mathrm{Cl}_{2} \cdot 4 \mathrm{H}_{2} \mathrm{O}$ and $0.2 \mathrm{M} \mathrm{Fe}(\mathrm{III}) \mathrm{Cl}_{3} \cdot 6 \mathrm{H}_{2} \mathrm{O}$ were maintained at $\mathrm{pH} 7$ by adding an appropriate amount of $1 \mathrm{M} \mathrm{Na}_{2} \mathrm{CO}_{3}$ solution. The $\mathrm{Fe}(\mathrm{III}) \mathrm{Cl}_{3} \cdot 6 \mathrm{H}_{2} \mathrm{O}$ solution was then added into the $\mathrm{Fe}(\mathrm{II}) \mathrm{Cl}_{2} \cdot 4 \mathrm{H}_{2} \mathrm{O}$ solution and the mixed solution was thereafter maintained at $\mathrm{pH} 8$ by adding $1 \mathrm{M} \mathrm{Na}_{2} \mathrm{CO}_{3}$ solution. The mixed solution of $\mathrm{Fe}(\mathrm{II}) / \mathrm{Fe}$ (III) was stirred for about 1 hour until a blue-green precipitate was formed. The blue-green precipitate (i.e., $\mathrm{GR}\left(\mathrm{CO}_{3}{ }^{2-}\right)$ ) was filtered in a vacuum under an anoxic condition and washed 3 to 4 times with Milli$Q$ water. The synthesized $\operatorname{GR}\left(\mathrm{CO}_{3}{ }^{2}\right)$ was immediately used in sorption experiments because it could change into magnetite or other iron oxides even in a glove box condition $\left(\mathrm{O}_{2}<10 \mathrm{ppm}\right)$.

\subsubsection{GR chloride, $\mathrm{GR}\left(\mathrm{Cl}^{-}\right)$}

GR chloride, $\mathrm{GR}(\mathrm{Cl})$, was synthesized using the method of Refait et al. [26]. $\mathrm{Fe}(\mathrm{II}) \mathrm{Cl}_{2} \cdot 4 \mathrm{H}_{2} \mathrm{O}$ in powder form (7.95 g) was dissolved in $70 \mathrm{~mL}$ of a $0.5 \mathrm{M} \mathrm{NaCl}$ solution. The prepared solution was adjusted to $\mathrm{pH} 7.5$ using a $5 \mathrm{M}$ $\mathrm{NaOH}$ solution. The solution was stirred for about 2 hours until the $\mathrm{pH}$ of the solution decreased to 6.5. A suspension solution containing precipitated $\mathrm{Fe}(\mathrm{II})(\mathrm{OH})_{2}(\mathrm{~s})$ was thereby formed from the reaction of $\mathrm{Fe}(\mathrm{II}) \mathrm{Cl}_{2} \cdot 4 \mathrm{H}_{2} \mathrm{O}$ with the $\mathrm{NaOH}$ solution while stirring the solution. A $1.0 \mathrm{M}$ perhydroxide $\left(\mathrm{H}_{2} \mathrm{O}_{2}\right)$ solution was injected slowly in the suspension solution of $\mathrm{Fe}(\mathrm{II})(\mathrm{OH})_{2}(\mathrm{~s})$ according to a molar ratio of $\left[\mathrm{Fe}(\mathrm{II}) \mathrm{Cl}_{2} \cdot 4 \mathrm{H}_{2} \mathrm{O}\right] /\left[\mathrm{H}_{2} \mathrm{O}_{2}\right]=8.5$ until a blue-green precipitate was formed. The blue-green precipitate (i.e., $\mathrm{GR}(\mathrm{Cl})$ ) was filtered in a vacuum under an anoxic condition and washed 3 to 4 times with Milli-Q water. Afterward, the $\mathrm{GR}(\mathrm{Cl})$ particles were suspended again in Milli-Q water for sorption experiments. However, $\mathrm{Cl}^{-}$still existed in the $\mathrm{GR}(\mathrm{Cl})$ suspension with a concentration of about $50 \mathrm{mM}$ after the aforementioned washing step with Milli-Q water. The synthesized $\mathrm{GR}(\mathrm{Cl})$ suspension was immediately used in sorption experiments to avoid oxidation of the synthesized $\mathrm{GR}\left(\mathrm{Cl}^{-}\right)$.

\subsection{Sorption experiments}

\subsubsection{Sorption of selenite and selenate}

Two separate $20 \mathrm{~mL}$ solutions of $0.01 \mathrm{mM} \mathrm{Na}_{2} \mathrm{Se}(\mathrm{IV}) \mathrm{O}_{3}$ and $0.01 \mathrm{mM} \mathrm{Na}_{2} \mathrm{Se}(\mathrm{VI}) \mathrm{O}_{4}$ were prepared in a $10 \mathrm{mM}$ $\mathrm{NaClO}_{4}$ solution. $\mathrm{GR}\left(\mathrm{CO}_{3}{ }^{2-}\right)$ in powder form $(0.65 \mathrm{~g})$ was added to the prepared solutions for the sorption reaction. In addition, $1 \mathrm{mM} \mathrm{Na}_{2} \mathrm{SiO}_{3}$ was introduced to investigate the effect of silicate ions on the sorption of selenium onto $\mathrm{GR}\left(\mathrm{CO}_{3}{ }^{2-}\right)$. The $\mathrm{pH}$ of the solutions reacted with $\mathrm{GR}\left(\mathrm{CO}_{3}{ }^{2-}\right)$ was adjusted to about 9 using $0.01 \mathrm{M}$ and $0.1 \mathrm{M}$ $\mathrm{NaOH}$ solutions during shaking for 1 hour. After the reaction time of 1 hour, the amount of selenium sorbed on the GR was calculated from the concentration difference between the initial and final concentrations of selenium in the solution. The reaction time of 1 hour was arbitrarily chosen for ease of experiments. The reaction time may be sufficient for the sorption reaction (particularly for anion exchange reaction) but insufficient for reduction of $\mathrm{Se}(\mathrm{IV})$ into $\mathrm{Se}(0)$.

In the presence of $\mathrm{GR}\left(\mathrm{CO}_{3}{ }^{2-}\right)$, final Eh values of the reaction solutions ranged from -240 to $-220 \mathrm{mV}$ without the addition of a chemical reducer. A strong reducer $\left(100 \mathrm{mM} \mathrm{N} \mathrm{H}_{2}\right.$ and $20 \mathrm{mM} \mathrm{Fe}(\mathrm{II}) \mathrm{Cl}_{2} \cdot 4 \mathrm{H}_{2} \mathrm{O}$ ) was added to $1 \mathrm{mM} \mathrm{Na} 2 \mathrm{Se}(\mathrm{IV}) \mathrm{O}_{3}$ solutions in the absence of $\mathrm{GR}\left(\mathrm{CO}_{3}{ }^{2-}\right)$ to investigate the oversaturation solubility of $\mathrm{Se}(\mathrm{IV}) \mathrm{O}_{3}{ }^{2-}$ owing to the reduction of $\mathrm{Se}(\mathrm{IV}) \mathrm{O}_{3}{ }^{2-}$ into metal selenium, $\mathrm{Se}(0)$, under given experimental conditions (see Fig. 1).

\subsubsection{Sorption of iodide}

Some $20 \mathrm{~mL}$ solutions of 0.01 to $1 \mathrm{mM} \mathrm{NaI}$ were prepared in a $10 \mathrm{mM} \mathrm{NaClO} 4$ solution. $\mathrm{GR}\left(\mathrm{CO}_{3}{ }^{2-}\right)$ in powder form $(0.65 \mathrm{~g})$ was added to all prepared solutions for the sorption reaction. The $\mathrm{pH}$ of the reacting solutions containing $\mathrm{GR}\left(\mathrm{CO}_{3}{ }^{2-}\right)$ was adjusted to about 9.0 using $0.01 \mathrm{M}$ and $0.1 \mathrm{M} \mathrm{NaOH}$ solutions. Sorption experiments of iodide onto $\mathrm{GR}\left(\mathrm{CO}_{3}{ }^{2-}\right)$ were conducted for $1.5,72$, and 168 hours. Final Eh values of the reaction solutions were measured as -240 to $-220 \mathrm{mV}$ in the presence of $\mathrm{GR}\left(\mathrm{CO}_{3}{ }^{2-}\right)$ without the addition of a chemical reducer. The amount of iodide sorbed on the $\mathrm{GR}\left(\mathrm{CO}_{3}{ }^{2-}\right)$ was calculated from the concentration difference between the initial and final concentrations of iodide in the solution.

A sorption experiment was also carried out to investigate the effect of dissolved $\mathrm{Cl}^{-}$on the $\mathrm{I}^{-}$sorption onto $\mathrm{GR}\left(\mathrm{Cl}^{-}\right)$as a function of the $[\mathrm{Cl}] /\left[\mathrm{I}^{-}\right]$ratio. For the experiment, $12.5 \mathrm{~mL}$ solutions of 0.260 to $10 \mu \mathrm{M} \mathrm{NaI}$ were added to a $5 \mathrm{~mL}$ solution of $\mathrm{GR}(\mathrm{Cl})$ and $7.5 \mathrm{~mL}$ solutions of 86 to $260 \mu \mathrm{M} \mathrm{NaI}$ were added to a $10 \mathrm{~mL}$ solution of $\mathrm{GR}\left(\mathrm{Cl}^{-}\right)$. The concentration of $\mathrm{Cl}^{-}$in the solution was controlled by adjusting the volume of $\mathrm{GR}\left(\mathrm{Cl}^{-}\right)$ 
added, because the $\mathrm{GR}\left(\mathrm{Cl}^{-}\right)$suspension was stored in a $50 \mathrm{mM} \mathrm{NaCl}$ solution. The amount of $\mathrm{GR}(\mathrm{Cl})$ existing in the suspension solution was determined to be $0.25 \mathrm{~g}$ after freeze-drying the $10 \mathrm{~mL}$ suspension solution.

The $\mathrm{pH}$ of the reaction solutions was adjusted to 7.5 to 8 using $0.1 \mathrm{M}$ and $1.0 \mathrm{M} \mathrm{NaOH}$ solutions. Sorption experiments of iodide onto $\mathrm{GR}(\mathrm{Cl})$ were conducted for 1, 14, and 96 hours. The final Eh values of the reaction solutions were measured as about $-400 \mathrm{mV}$ in the presence of $\mathrm{GR}\left(\mathrm{Cl}^{-}\right)$without the addition of a chemical reducer.

\section{RESULTS AND DISCUSSIONS}

\subsection{Sorption of selenite onto $\mathrm{GR}\left(\mathrm{CO}_{3}{ }^{2}\right)$}

Experimental conditions and results for the sorption of $\mathrm{Se}(\mathrm{IV}) \mathrm{O}_{3}{ }^{2-}$ onto $\mathrm{GR}\left(\mathrm{CO}_{3}{ }^{2-}\right)$ are shown in Table 1 . It is well known that $\mathrm{Se}(\mathrm{IV}) \mathrm{O}_{3}{ }^{2-}$ can be reduced to $\mathrm{Se}(0)$ in a strong reduction condition $[4,14,27-30]$. Oversaturation solubility experiments of $\mathrm{Se}(\mathrm{IV}) \mathrm{O}_{3}{ }^{2-}$ were thus carried out to determine the initial concentration of $\mathrm{Se}(\mathrm{IV}) \mathrm{O}_{3^{2-}}$ before the sorption experiments. As shown in Table. 1, the oversaturation solubility of $\mathrm{Se}(\mathrm{IV}) \mathrm{O}_{3}{ }^{2-}$ was measured as $0.42 \mathrm{mM}$ in a $100 \mathrm{mM} \mathrm{N}_{2} \mathrm{H}_{4}$ solution $(\mathrm{pH} 9.81$ and $\mathrm{Eh}$ $=-310 \mathrm{mV}$ for 7 days) and as $0.61 \mathrm{mM}$ in a $20 \mathrm{mM}$ $\mathrm{Fe}(\mathrm{II}) \mathrm{Cl}_{2} \cdot 4 \mathrm{H}_{2} \mathrm{O}$ solution ( $\mathrm{pH} 4.7$ and $\mathrm{Eh}=-170 \mathrm{mV}$ for 1 hour) when the initial concentrations of $\mathrm{Se}(\mathrm{IV}) \mathrm{O}_{3}{ }^{2-}$ were $1 \mathrm{mM}$ and $0.95 \mathrm{mM}$ for the two solutions, respectively. Thus we used a much lower initial concentration of $\mathrm{Se}(\mathrm{IV}) \mathrm{O}_{3}{ }^{2-}, 1.3 \times 10^{-5} \mathrm{M}$, than the measured oversaturation solubility values for the sorption experiments to avoid precipitation of $\mathrm{Se}(\mathrm{IV}) \mathrm{O}_{3}{ }^{2-}$ as $\mathrm{Se}(0)$ by reduction.
The solubility of selenite greatly depends upon the redox condition above $\mathrm{pH} 8$, especially in the vicinity of the boundary conditions of $\mathrm{Se}(0)$ [27] (see Fig. 1). In fact, the initial concentration of $\mathrm{Se}(\mathrm{IV}) \mathrm{O}_{3}^{2-}$ (i.e., $1.3 \times 10^{-5} \mathrm{M}$ ) was expected to be higher than the solubility of $\operatorname{Se}(0)$ at $\mathrm{pH} 9$ and $\mathrm{Eh}=-240$ to $-220 \mathrm{mV}$. However, some studies reported that reduction of $\mathrm{Se}(\mathrm{IV}) \mathrm{O}_{3}{ }^{2-}$ to $\mathrm{Se}(0)$ is a slow process even in the presence of reducing agents such as $\mathrm{Fe}(\mathrm{II})$-containing minerals and reducing bacteria [28, 29]. For instance, Myneni et al. [30] reported that $\mathrm{Se}(\mathrm{VI}) \mathrm{O}_{4}{ }^{2-}$ was rapidly reduced to $\mathrm{Se}(\mathrm{IV}) \mathrm{O}_{3}{ }^{2-}$ by $\mathrm{GR}\left(\mathrm{SO}_{4}{ }^{2-}\right)$ but the formed $\mathrm{Se}(\mathrm{IV}) \mathrm{O}_{3}{ }^{2-}$ was slowly reduced to $\mathrm{Se}(0)$ by $\mathrm{GR}\left(\mathrm{SO}_{4}{ }^{2-}\right)$. Recently, Schellenger and LareseCasanova [24] reported that $\mathrm{Se}(\mathrm{VI})$ was reduced rapidly but $\mathrm{Se}(0)$ formed very slowly. It was also reported from an experiment using $\mathrm{GR}\left(\mathrm{SO}_{4}{ }^{2}\right)$ that sorption is a major removal mechanism for $\mathrm{Se}(\mathrm{IV})$ and reduction is not necessarily the dominant removal process [31]. In our experimental system, all sorption experiments were conducted for 1 hour. The possibility $\mathrm{Se}(\mathrm{IV}) \mathrm{O}_{3}{ }^{2-}$ being reduced to $\operatorname{Se}(0)$ thus appears to be very low because the reduction of $\mathrm{Se}(\mathrm{IV})$ to $\mathrm{Se}(0)$ would be a slow process that may require more than 1 hour. Table 1 shows that most of the $\mathrm{Se}(\mathrm{IV}) \mathrm{O}_{3}{ }^{2-}$ was removed quickly from the solution during 1 hour by $\mathrm{GR}\left(\mathrm{CO}_{3}{ }^{2-}\right)$. It can thus be presumed that the removal of $\mathrm{Se}(\mathrm{IV}) \mathrm{O}_{3}{ }^{2-}$ from the solution is due to sorption onto $\mathrm{GR}\left(\mathrm{CO}_{3}{ }^{2-}\right)$, not to reduction to $\operatorname{Se}(0)$.

As shown in Table 1, most of the $\mathrm{Se}(\mathrm{IV}) \mathrm{O}_{3}{ }^{2-}$ was removed from the solutions regardless of the pre ence of silicate ions, which dominantly exist as $\mathrm{H}_{4} \mathrm{SiO}_{4}$ at given conditions. It was reported that $\mathrm{H}_{4} \mathrm{SiO}_{4}$ dissolved in a solution can hinder the chemical adsorption of $\mathrm{Se}(\mathrm{IV}) \mathrm{O}^{2-}$ onto iron oxide $[3,32]$. However, in this study, the sorption of $\mathrm{Se}(\mathrm{IV}) \mathrm{O}_{3}{ }^{2-}$ onto $\mathrm{GR}\left(\mathrm{CO}_{3}{ }^{2-}\right)$ was not

Table 1. Experimental conditions and results for the sorption of selenium onto synthesized $\mathrm{GR}\left(\mathrm{CO}_{3}{ }^{2-}\right)$

\begin{tabular}{|c|c|c|c|c|c|c|c|c|}
\hline \multirow{2}{*}{$\begin{array}{c}\mathrm{GR}\left(\mathrm{CO}_{3}{ }^{2-}\right) \\
(\mathrm{g} / \mathrm{L})\end{array}$} & \multicolumn{2}{|c|}{$[\mathrm{Se}]_{\text {initial }}(\mathrm{M})$} & \multirow{2}{*}{$\begin{array}{l}\mathrm{Na}_{2} \mathrm{SiO}_{3} \\
\text { (M) }\end{array}$} & \multirow{2}{*}{$\mathrm{pH}_{\text {final }}$} & \multirow{2}{*}{$\begin{array}{l}\text { Ehfinal } \\
(\mathrm{mV})\end{array}$} & \multirow{2}{*}{ Reducing agent } & \multirow{2}{*}{$\begin{array}{l}{[\mathrm{Se}]_{\text {final }}} \\
(\mathrm{M})\end{array}$} & \multirow{2}{*}{$\begin{array}{l}{[\mathrm{Se}]_{\text {sorbec }}} \\
\quad(\%)\end{array}$} \\
\hline & $\mathrm{Se}(\mathrm{IV}) \mathrm{O}_{3}{ }^{2-}$ & $\mathrm{Se}(\mathrm{VI}) \mathrm{O}_{4}{ }^{2-}$ & & & & & & \\
\hline - & $\begin{array}{l}1.0 \times 10^{-3} \\
9.5 \times 10^{-4}\end{array}$ & - & - & $\begin{array}{c}9.81 \\
4.7\end{array}$ & $\begin{array}{l}-310 \\
-170\end{array}$ & $\begin{array}{c}100 \mathrm{mM} \mathrm{N}_{2} \mathrm{H}_{4} \\
\left.20 \mathrm{mM} \mathrm{Fe}^{\mathrm{II}}\right) \mathrm{Cl}_{2}\end{array}$ & $\begin{array}{l}4.2 \times 10^{-4} \\
6.1 \times 10^{-4}\end{array}$ & \\
\hline 32.5 & $\begin{array}{l}1.3 \times 10^{-5} \\
1.3 \times 10^{-5} \\
1.3 \times 10^{-5} \\
1.3 \times 10^{-5}\end{array}$ & $\begin{array}{l}- \\
- \\
- \\
-\end{array}$ & $\begin{array}{c}1.0 \times 10^{-3} \\
1.0 \times 10^{-3} \\
- \\
-\end{array}$ & $\begin{array}{l}9.00 \\
8.90 \\
8.91 \\
8.96\end{array}$ & $\begin{array}{l}-240- \\
-220\end{array}$ & - & $\begin{array}{l}2.0 \times 10^{-7} \\
2.4 \times 10^{-7} \\
3.4 \times 10^{-7} \\
3.9 \times 10^{-7}\end{array}$ & $\begin{array}{l}98 \\
98 \\
97 \\
97\end{array}$ \\
\hline 32.5 & $\begin{array}{l}- \\
- \\
- \\
-\end{array}$ & $\begin{array}{l}1.4 \times 10^{-5} \\
1.4 \times 10^{-5} \\
1.4 \times 10^{-5} \\
1.4 \times 10^{-5}\end{array}$ & $\begin{array}{c}1.0 \times 10^{-3} \\
1.0 \times 10^{-3} \\
- \\
-\end{array}$ & $\begin{array}{l}8.98 \\
9.03 \\
9.00 \\
9.00\end{array}$ & $\begin{array}{l}-240- \\
-220\end{array}$ & - & $\begin{array}{l}7.9 \times 10^{-6} \\
8.8 \times 10^{-6} \\
7.9 \times 10^{-6} \\
1.0 \times 10^{-5}\end{array}$ & $\begin{array}{l}44 \\
37 \\
44 \\
29\end{array}$ \\
\hline
\end{tabular}

※ All experiments were conducted in $10 \mathrm{mM} \mathrm{NaClO}_{4}$ solution. 
affected by the presence of $\mathrm{H}_{4} \mathrm{SiO}_{4}$ even at a 100 times higher concentration than that of $\mathrm{Se}(\mathrm{IV}) \mathrm{O}_{3}{ }^{2-}$. It is thus surmised that a sorption process other than chemical adsorption can occur during the sorption of $\mathrm{Se}(\mathrm{IV}) \mathrm{O}_{3}{ }^{2-}$ onto $\mathrm{GR}\left(\mathrm{CO}_{3}{ }^{2-}\right)$. When $\mathrm{Se}(\mathrm{IV}) \mathrm{O}_{3}{ }^{2-}$ is reacted with $\mathrm{GR}\left(\mathrm{CO}_{3}{ }^{2-}\right)$, the anion $\mathrm{Se}(\mathrm{IV}) \mathrm{O}_{3}{ }^{2-}$ can be exchanged with $\mathrm{CO}_{3}^{2-}$ existing in the interlayer of $\mathrm{GR}\left(\mathrm{CO}_{3}{ }^{2-}\right)$ by an anion exchange process. This anion exchange mechanism of $\mathrm{Se}(\mathrm{IV}) \mathrm{O}_{3}{ }^{2-}$ with $\mathrm{GR}\left(\mathrm{CO}_{3}{ }^{2-}\right)$ can be explained by $\mathrm{Se}(\mathrm{IV}) \mathrm{O}_{3}{ }^{2-}$ having the same geometry (a planar structure) and charge as $\mathrm{CO}_{3}{ }^{2-}$ existing in the interlayer of $\mathrm{GR}\left(\mathrm{CO}_{3}{ }^{2-}\right)$. Thus, as shown in Table 1, $\mathrm{Se}(\mathrm{IV}) \mathrm{O}_{3}{ }^{2-}$ was considered to be mostly sorbed on $\mathrm{GR}\left(\mathrm{CO}_{3}{ }^{2-}\right)$ by an anion exchange process.

\subsection{Sorption of Selenate onto $\mathrm{GR}\left(\mathrm{CO}_{3}{ }^{2-}\right)$}

Experimental conditions and results for the sorption of $\mathrm{Se}(\mathrm{VI}) \mathrm{O}_{4}{ }^{2-}$ onto $\mathrm{GR}\left(\mathrm{CO}_{3}{ }^{2-}\right)$ are also shown in Table 1. In the case $\mathrm{Se}(\mathrm{VI}) \mathrm{O}_{4^{2-}}$, much lower sorption onto $\mathrm{GR}\left(\mathrm{CO}_{3}{ }^{2-}\right)$ than that of $\mathrm{Se}(\mathrm{IV}) \mathrm{O}_{3}{ }^{2-}$ was expected since $\mathrm{Se}(\mathrm{VI}) \mathrm{O}_{4}{ }^{2-}$ has a different geometry (a three dimensional structure) from $\mathrm{CO}_{3}{ }^{2-}$ and a larger volume [33]. However, as shown in Table 1 , about 30 to $45 \%$ of $\mathrm{Se}(\mathrm{VI}) \mathrm{O}_{4}{ }^{2-}$ was sorbed onto $\mathrm{GR}\left(\mathrm{CO}_{3}{ }^{2-}\right)$ within 1 hour regardless of the presence of $\mathrm{SiO}_{3}{ }^{2-}$, contrary to our prediction of low sorption of $\mathrm{Se}(\mathrm{VI}) \mathrm{O}_{4}{ }^{2-}$ onto $\mathrm{GR}\left(\mathrm{CO}_{3}{ }^{2-}\right)$ due to the differences in physical properties between $\mathrm{Se}(\mathrm{VI}) \mathrm{O}_{4}{ }^{2-}$ and $\mathrm{CO}_{3}{ }^{2-}$ existing in the interlayer of $\mathrm{GR}\left(\mathrm{CO}_{3}{ }^{2-}\right)$. As previously mentioned, $\mathrm{Se}(\mathrm{VI}) \mathrm{O}_{4}{ }^{2-}$ can be reduced to $\mathrm{Se}(\mathrm{IV}) \mathrm{O}_{3}{ }^{2-}$ and/or $\mathrm{Se}(0)$ by the $\mathrm{Fe}(\mathrm{II})$ present in $\mathrm{GR}\left(\mathrm{CO}_{3}{ }^{2-}\right)$ depending on reaction kinetics. The notable sorption of $\mathrm{Se}(\mathrm{VI}) \mathrm{O}_{4^{2-}}$ onto $\mathrm{GR}\left(\mathrm{CO}_{3}{ }^{2-}\right)$ can thus be explained by the following two sequential processes: (1) $\mathrm{Se}(\mathrm{VI}) \mathrm{O}_{4^{2-}}$ may be reduced to $\mathrm{Se}(\mathrm{IV}) \mathrm{O}_{3}{ }^{2-}$ by $\mathrm{Fe}(\mathrm{II})$ existing on the external surface sites

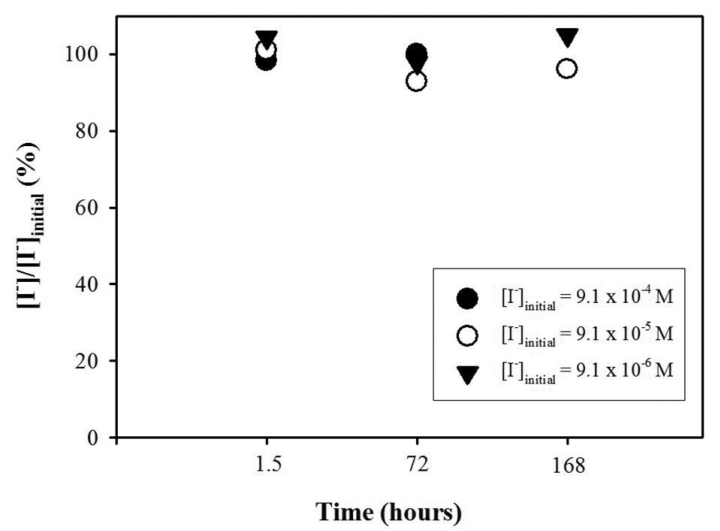

Fig. 3. The percentage of $\mathrm{I}^{-}$remaining in the solution in presence presence of $\mathrm{GR}\left(\mathrm{CO}_{3}{ }^{2}\right)$ as a function of contact time at $\mathrm{NaClO}_{4}=10 \mathrm{mM}$ and $\mathrm{m}_{\mathrm{GR}\left(\mathrm{CO}_{3}{ }^{2}\right)} / \mathrm{V}_{\mathrm{sol}}=33-37 \mathrm{~g} / \mathrm{L}$. of $\mathrm{GR}\left(\mathrm{CO}_{3}{ }^{2-}\right)$, and (2) the reduced $\mathrm{Se}(\mathrm{IV}) \mathrm{O}_{3}{ }^{2-}$ from $\mathrm{Se}(\mathrm{VI}) \mathrm{O}_{4}{ }^{2-}$ will be sorbed onto $\mathrm{GR}\left(\mathrm{CO}_{3}{ }^{2-}\right)$, because $\mathrm{Se}(\mathrm{IV}) \mathrm{O}_{3}{ }^{2-}$ can be quickly exchanged with $\mathrm{CO}_{3}{ }^{2-}$ existing in the interlayer of $\mathrm{GR}\left(\mathrm{CO}_{3}{ }^{2-}\right)$. Otherwise, $\mathrm{Se}(\mathrm{VI}) \mathrm{O}_{4}{ }^{2-}$ can be removed from the solution by direct reduction to $\mathrm{Se}(0)$, but this may not be a favorable mechanism for the removal of $\mathrm{Se}(\mathrm{VI}) \mathrm{O}_{4}{ }^{2-}$ during the considered reaction time of 1 hour [30, 31].

\subsection{Sorption of iodide onto $\mathrm{GR}\left(\mathrm{CO}_{3}{ }^{2-}\right)$}

The sorption of I- onto $\mathrm{GR}\left(\mathrm{CO}_{3}{ }^{2-}\right)$ was conducted in $10 \mathrm{mM}$ $\mathrm{NaClO}_{4}$ with varying concentrations from 0.01 to $1 \mathrm{mM}$ for $1.5,72$, and 168 hours. $\mathrm{I}^{-}$is expected to exist mostly as dissolved species because its solubility is very high at both oxidized and reduced conditions [34]. It is known that $\mathrm{I}^{-}$can be sorbed onto strong cation sites $\left(\equiv \mathrm{FeOH}_{2}{ }^{+}\right)$ of iron oxides of $\mathrm{pH}$ usually below 5 , forming outersphere surface complexes [15]. However, I- will not be sorbed on weak cation sites $(\equiv \mathrm{FeOH})$ and anion sites ( $\equiv$ $\mathrm{FeO}^{-}$) of iron oxides of $\mathrm{pH}$ usually above 5 [15]. Anion exchange between $\mathrm{I}^{-}$and $\mathrm{CO}_{3}{ }^{2-}$ existing in the interlayer of $\mathrm{GR}\left(\mathrm{CO}_{3}{ }^{2-}\right)$ was expected to occur, such as $\mathrm{Se}(\mathrm{IV}) \mathrm{O}_{3}{ }^{2-}$. However, as shown in Fig. 3, the removal of I- was not observed. Based upon the assumption that the sorption of $\mathrm{I}^{-}$onto $\mathrm{GR}\left(\mathrm{CO}_{3}{ }^{2-}\right)$ occur by an anion exchange process, this different sorption behavior of $\mathrm{I}^{-}$from $\mathrm{Se}(\mathrm{IV}) \mathrm{O}_{3}{ }^{2-}$ can be explained by the differences in their physical and chemical properties. $\mathrm{CO}_{3}{ }^{2-}$ has a planar geometry and -2 charges whereas I- has a monomolecular structure and -1 charge. The different physical and chemical properties of I from $\mathrm{CO}_{3}{ }^{2-}$ would thus impede diffusion of $\mathrm{I}$ into the interlayer of $\mathrm{GR}\left(\mathrm{CO}_{3}{ }^{2-}\right)$, and exchange with $\mathrm{CO}_{3}{ }^{2-}$ existing in the interlayer of $\mathrm{GR}\left(\mathrm{CO}_{3}{ }^{2-}\right)$ thus does not readily occur.

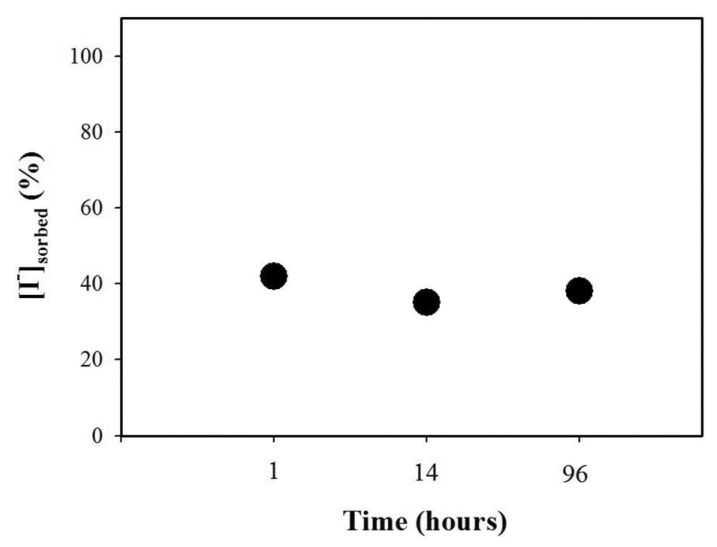

Fig. 4. The percentage of $\mathrm{I}^{-}$sorbed onto $\mathrm{GR}\left(\mathrm{Cl}^{-}\right)$as a function of contact time at $\mathrm{NaClO}_{4}=10 \mathrm{mM}$ and $\left.\operatorname{maR}_{\mathrm{GO}_{3}}{ }^{2}\right) / \mathrm{V}_{\text {sol }}=12.5 \mathrm{~g} / \mathrm{L}$. 
M. H. Baik et al. : Sorption of I and Se onto Green Rusts with Different Interlayer Anions, $\mathrm{GR}\left(\mathrm{CO}_{3^{2-}}\right)$ and $\mathrm{GR}\left(\mathrm{Cl}^{-}\right)$

Table 2. Experimental conditions and results for the sorption of iodide onto synthesized $\mathrm{GR}(\mathrm{Cl})$

\begin{tabular}{|c|c|c|c|c|c|c|c|c|}
\hline $\begin{array}{c}\mathrm{GR}(\mathrm{Cl}) \\
(\mathrm{g} / \mathrm{L})\end{array}$ & $\begin{array}{l}[\mathrm{I}]]_{\text {intial }} \\
(\mathrm{M})\end{array}$ & $\begin{array}{l}{[\mathrm{Cl}]_{\text {initial }}} \\
(\mathrm{M})\end{array}$ & {$\left[\mathrm{Cl}^{-}\right] /\left[\mathrm{I}^{-}\right]$} & $\mathrm{pH}_{\text {final }}$ & $\begin{array}{l}\mathrm{Eh}_{\text {final }} \\
(\mathrm{mV})\end{array}$ & $\begin{array}{l}{[\mathrm{I}]_{\text {final }}} \\
(\mathrm{M})\end{array}$ & $\begin{array}{l}{[\mathrm{I}]_{\text {initial }}\left[-[\mathrm{I}]_{\text {final }}\right.} \\
\text { (M) }\end{array}$ & $\begin{array}{c}{[\mathrm{I}]_{\text {orobed }}} \\
(\%)\end{array}$ \\
\hline 14.3 & $\begin{array}{l}2.6 \times 10^{-4} \\
8.6 \times 10^{-5}\end{array}$ & $2.8 \times 10^{-2}$ & $\begin{array}{l}1.1 \times 10^{2} \\
3.3 \times 10^{2}\end{array}$ & $\begin{array}{l}7.67 \\
7.57\end{array}$ & -400 & $\begin{array}{l}2.1 \times 10^{-4} \\
4.9 \times 10^{-5}\end{array}$ & $\begin{array}{l}5.2 \times 10^{-5} \\
3.7 \times 10^{-5}\end{array}$ & $\begin{array}{l}20 \\
43\end{array}$ \\
\hline 7.2 & $\begin{array}{l}1.0 \times 10^{-5} \\
1.0 \times 10^{-6} \\
2.6 \times 10^{-7}\end{array}$ & $1.4 \times 10^{-2}$ & $\begin{array}{l}1.4 \times 10^{3} \\
1.4 \times 10^{4} \\
5.5 \times 10^{4}\end{array}$ & $\begin{array}{l}7.90 \\
7.89 \\
7.90\end{array}$ & -400 & $\begin{array}{l}7.1 \times 10^{-6} \\
7.7 \times 10^{-7} \\
2.0 \times 10^{-7}\end{array}$ & $\begin{array}{l}3.3 \times 10^{-6} \\
2.6 \times 10^{-7} \\
6.3 \times 10^{-8}\end{array}$ & $\begin{array}{l}28 \\
23 \\
22\end{array}$ \\
\hline
\end{tabular}

※ All experiments were conducted in $10 \mathrm{mM} \mathrm{NaClO}_{4}$ solution.

\subsection{Sorption of iodide onto $\mathrm{GR}\left(\mathrm{Cl}^{-}\right)$}

As shown in Fig. 4, the sorption of $\mathrm{I}^{-}$onto $\mathrm{GR}\left(\mathrm{Cl}^{-}\right)$ occurred quickly, within 1 hour, although the sorption experiment was conducted for 1, 14, and 96 hours. Experimental conditions and results for the sorption of I onto $\mathrm{GR}(\mathrm{Cl})$ are shown in Table 2. As shown in Table 2, about 20 to $43 \%$ of I- was sorbed onto $\mathrm{GR}\left(\mathrm{Cl}^{-}\right)$; this result is very different from that of $\operatorname{GR}\left(\mathrm{CO}_{3}{ }^{2}\right)$, which showed no sorption of $\mathrm{I}^{-}$. This difference in the sorption behavior of $\mathrm{I}^{-}$for $\mathrm{GR}(\mathrm{Cl})$ and $\mathrm{GR}\left(\mathrm{CO}_{3}{ }^{2-}\right)$ may be due to $\mathrm{I}^{-}$ having the same geometry and charge as $\mathrm{Cl}^{\text {. The amount }}$ of $\mathrm{I}^{-}$sorbed onto $\mathrm{GR}\left(\mathrm{Cl}^{-}\right)$as a function of the $\left[\mathrm{Cl}^{-}\right] /\left[\mathrm{I}^{-}\right]$ ratio is shown in Fig. 5. The results show a linear relationship between $\left[\mathrm{I}^{-}\right]_{\text {sorbed }}$ and $\left[\mathrm{Cl}^{-}\right] /\left[\mathrm{I}^{-}\right]$. This linear relationship implies that the sorption of $\mathrm{I}^{-}$onto $\mathrm{GR}\left(\mathrm{Cl}^{-}\right)$ depends on the concentration of $\mathrm{Cl}^{-}$dissolved in solution, which competes with $\mathrm{I}^{-}$against sorption onto $\mathrm{GR}\left(\mathrm{Cl}^{-}\right)$. Consequently, $\mathrm{I}^{-}$and $\mathrm{Cl}^{-}$dissolved in solution will be competitively exchanged with $\mathrm{Cl}^{-}$existing in the interlayer of $\mathrm{GR}(\mathrm{Cl})$. In addition, $\mathrm{GR}(\mathrm{Cl})$ exchanged

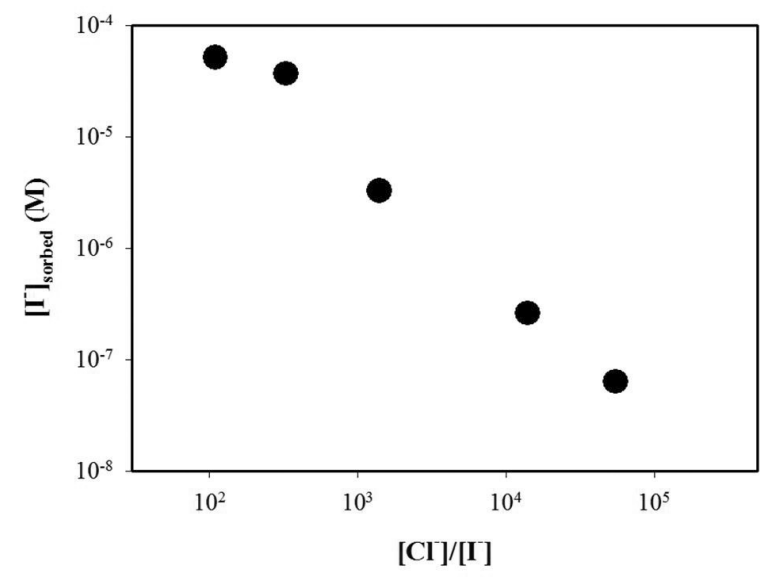

Fig. 5. The amount of $\mathrm{I}^{-}$sorbed onto $\mathrm{GR}\left(\mathrm{Cl}^{-}\right)$as a function of $\left[\mathrm{Cl}^{-}\right] /\left[\mathrm{I}^{-}\right]$ ratio dissolved in solution at $\mathrm{NaClO}_{4}=10 \mathrm{mM}$ and $\mathrm{m}_{\mathrm{GR}\left(\mathrm{CO}_{3}{ }^{2}\right)} / \mathrm{V}_{\mathrm{sol}}=$ $7.1-14.2 \mathrm{~g} / \mathrm{L}$. with $\mathrm{I}^{-}$will be changed into GR(I-). This dependency of $\mathrm{I}^{-}$ sorption on the concentration of $\mathrm{Cl}^{-}$dissolved in solution also supports the finding that the sorption of $\mathrm{I}^{-}$onto $\mathrm{GR}\left(\mathrm{Cl}^{-}\right)$mainly occurred by an anion exchange process between $\mathrm{I}^{-}$and $\mathrm{Cl}^{-}$.

\section{CONCLUSION}

The sorption of iodide and selenium onto green rust was studied to investigate the influence of green rust on the migration of anions such as selenite, selenate, and iodide considering different structures of green rust, i.e., $\mathrm{GR}\left(\mathrm{Cl}^{-}\right)$and $\mathrm{GR}\left(\mathrm{CO}_{3}{ }^{2-}\right)$. The experimental results showed that most $\mathrm{Se}(\mathrm{IV}) \mathrm{O}_{3}{ }^{2}$ was sorbed onto $\mathrm{GR}\left(\mathrm{CO}_{3}{ }^{2}\right)$ within 1 hour by anion exchange with $\mathrm{CO}_{3}{ }^{2}$ existing in the interlayer of $\mathrm{GR}\left(\mathrm{CO}_{3}{ }^{2}\right)$, regardless of the presence of $\mathrm{SiO}_{3}{ }^{2-}$. Some of the $\mathrm{Se}(\mathrm{VI}) \mathrm{O}_{4}{ }^{2-}$ was removed from the solution within 1 hour and this removal was presumed to be due to the sorption of $\mathrm{Se}(\mathrm{IV}) \mathrm{O}_{3}{ }^{2}$ onto $\mathrm{GR}\left(\mathrm{CO}_{3}{ }^{2}\right)$ following the reduction of $\mathrm{Se}(\mathrm{VI}) \mathrm{O}_{4}{ }^{2-}$ into $\mathrm{Se}(\mathrm{IV}) \mathrm{O}_{3}{ }^{2}$ by structural $\mathrm{Fe}$ (II) of $\mathrm{GR}\left(\mathrm{CO}_{3}{ }^{2}\right)$. For the sorption of I- onto $\mathrm{GR}\left(\mathrm{Cl}^{-}\right)$, I- was quickly sorbed onto $\mathrm{GR}\left(\mathrm{Cl}^{-}\right)$within 1 hour by anion exchange with $\mathrm{Cl}^{-}$existing in the interlayer of $\mathrm{GR}(\mathrm{Cl})$. However, I- was not sorbed onto $\mathrm{GR}\left(\mathrm{CO}_{3}{ }^{2}\right)$ due to the different physical and chemical properties of $\mathrm{I}^{-}$ from $\mathrm{CO}_{3}{ }^{2}$ existing in the interlayer of $\mathrm{GR}\left(\mathrm{CO}_{3}{ }^{2}\right)$.

In geological environments, $\mathrm{GR}\left(\mathrm{CO}_{3}{ }^{2}\right)$ can be formed in groundwater with a high carbonate concentration and $\mathrm{GR}\left(\mathrm{Cl}^{-}\right)$can be formed in groundwater near seawater or saline layers. The sorption of selenite and iodide onto $\mathrm{GR}\left(\mathrm{CO}_{3}{ }^{2}\right)$ and $\mathrm{GR}\left(\mathrm{Cl}^{-}\right)$, respectively, mainly occurs by anion exchange between the anionic radionuclides and the anions existing in the interlayer of $\mathrm{GR}\left(\mathrm{CO}_{3}{ }^{2}\right)$ and $\mathrm{GR}\left(\mathrm{Cl}^{-}\right)$. Green rusts may therefore play an important role in the retardation of anionic radionuclides such as selenite, selenate, and iodide depending upon the structural anions in radioactive waste disposal environments owing to their strong reducing potential by structural $\mathrm{Fe}(\mathrm{II})$ and anionic exchange capacity by the LDH structure. 


\section{ACKNOWLEDGEMENT}

This study was supported by the NRF (National Research Foundation of Korea) through the Nuclear R\&D program of the Ministry of Science, ICT and Future Planning (MSIP), Korea.

\section{REFERENCES}

[1] H.J. Choi, M. Lee and J.Y. Lee, Nucl. Eng. Design., 241, pp. 3348-3356 (2011)

[2] S.S. Kim, K.S. Chun, K.C. Kang, M.H. Baik, S.H. Kwon and J.W. Choi, J. Ind. Eng. Chem., 13, pp. 959-964 (2007)

[3] S.S. Kim, J.H. Min, J.K. Lee, M.H. Baik, J.W. Choi and H.S. Shin, J. Environ. Radioact., 104, pp. 1-6 (2012)

[4] T. Missana, U. Alonso, T.A.C. Scheinost, N. Granizo and M. Garcia-Gutierrez, Geochim. Cosmochim. Acta, 73, pp. 6205-6217 (2009)

[5] U. Schwertmann and H. Fechter, Clay Miner., 29, pp. 87-92 (1994)

[6] U. Schwertmann and R.M. Cornell, The Iron Oxides in the Laboratory (Preparation and Chracterization), Second, Completely Revised and Extended Edition, WILEY-VCH, Winheim, Germany (2008)

[7] L. Carlson, O. Karnland, V.M. Oversby, A. Rance, N. Smart, M. Snellman, M. Vähänen and L.O. Werme, Phys. Chem. Earth, 32, pp. 334-345 (2007)

[8] P. Refait, S.H. Drissi, J. Pytkiewicz and J.M.R. Génin, Corrosion Sci., 39, pp. 1699-1710 (1998)

[9] B. Kounde, A. Raharinaivo, A.A. Olowe, D. Rezel, P. Bauer and J.M.R. Génin, Hyperfine Interact., 46, pp. 421-428 (1989)

[10] J.M.R. Génin, A.A. Olowe, B. Resiak, M. Confenta, N. Rollet-Benbouzid, S. L'Haridon and D. Prieur, Hyperfine Interact., 93, pp. 1807-1812 (1994)

[11] J.M.R. Génin, A.A. Olowe, N.D. Benbouzid-Rollet, D. Prieur, M. Confente and B. Resiak, Hyperfine Interact., 69, pp. 875-878 (1991)

[12] P.P. Stampfl, Corrosion Sci., 9, pp. 185-187 (1969)

[13] J.M.R. Génin, P. Refait, L. Simon and S.H. Drissi, Hyperfine Interact., 11, pp. 313-318 (1998)

[14] M. Duc, G. Lefevre, M. Fedoroff, J. Jeanjean, J.C. Rocuchaud, F. Monteil-Rivera, J. Dumonceau and S. Milonjic, J. Environ. Radioact., 70, pp. 61-72 (2003)

[15] T. Nagata, K. Fukushi and Y. Takahashi, J. Coll. interf. Sci., 332, pp. 309-316 (2009)

[16] R.M. Cornell and U. Schwertmann, The Iron Oxides (Structure, Properties, Reactions,
Occurrences and Uses) Second, Completely Revised and Extended Edition, WILEY-VCH, Winheim, Germany (2003)

[17] P. Refait, A. Géhin, M. Abdelmoula and J.M.R. Génin, Corrosion Sci., 45, pp. 659-676 (2003)

[18] C. Ruby, R. Aissa, A. Géhin, J. Cortot, M. Abdelmoula and J.M.R. Génin, C. R. Geosci., 338, pp. 420-432 (2006)

[19] V. Rives, Layered double hydroxides: Present and future, New York: Noba Science (2001)

[20] B.C. Christiansen, T. Balic-Zunic, K. Dideriksen and S.L.S. Stipp, Environ. Sci. Technol., 32, pp. 3436-3441 (2009)

[21] D.G. Lewis, Adv. Geol. Ecol., 30, pp. 345-372 (1997)

[22] G. Bourrie and F. Trolard, Identification criteria forfougerite and nature of the interlayered anion, WILEY-VCH, Winheim, Germany (2010)

[23] P. Regait, L. Simon and J.-M.R. Génin, Environ. Sci. Technol., 34, pp. 819-825 (2000)

[24] A.E.P. Schellenger and P. Larese-Casanova, Environ.Sci. Technol., 47, pp. 6254-6262 (2013)

[25] R.M. Taylor, U. Schwertman and H. Fechter, Clay Miner., 20, pp. 147-151 (1985)

[26] P. Refait, M. Benali, Abdelmuoula and J.M.R. Génin, Corrosion Sci., 45, pp. 2435-2449 (2003)

[27] Y. Iida, T. Yamaguchi, T. Tanaka and S. Nakayama, J. Nucl. Sci. Technol., 47, pp. 431-438 (2010)

[28] L. Charlet, A.C. Scheinost, C. Tournassat, J.M. Greneche, A. Géhin, A. Fernández-Martínez, S. Scoudert, D. Tisserand and J. Brendle, Geochim. Cosmochim. Acta, 71, pp. 5731-5749 (2007)

[29] J. Kessi, M. Ramuz, E. Wehrli, M. Spycher and R. Bachofen, Appl. Environ. Microbiol., 65, pp. 47344740 (1999)

[30] S.C.B. Myneni, T.K. Tokunaga and G.E. Brown Jr., Science, 278, pp. 1106-1109 (1997)

[31] T.M. Johnson and T.D. Bullen, Geochim. Cosmochim. Acta, 67, pp. 413-419 (2003)

[32] N. Jordan, C. Lomenech, N. Marmier, E. Giffaut and J.J. Ehrhardt, J. Coll. Interf. Sci., 329, pp. 17-23 (2009)

[33] F. Chen, P.C. Burns and R.C. Ewing, J. Nucl. Mater., 275, pp. 81-94 (1999)

[34] T. Mioduski, C. Gumiński and D. Zeng, J. Phys. Chem. Ref. Data, 41, 013104 (2012) 